\title{
Computerized Control Strategy to Prevent Wastewater Plants Pollution
}

\author{
Yolanda Bolea, Antoni Grau, Herminio Martinez \\ Automatic Control Dept, Technical University of Catalonia UPC, Barcelona, Spain \\ \{yolanda.bolea; antoni.grau,herminio.martinez\}@upc.edu
}

\begin{abstract}
Pollution in coastal areas is very hazardous for population. The problem is even higher when this pollution occurs in bathing areas such as beaches in populated areas. In this work we present a new automatic control application for wastewater plants when pollution is caused by those plants because there is an excess of water to be treated and it is thrown to the sea with high levels of biological pollutants (bacteria...). Those problems can be aggravated if climatic conditions pull to the coastal area the untreated water without the cleaning action of sea water. The experimentation is done with real data and real conditions in Barcelona area, at Mediterranean sea, with the urban wastewater plant of Besòs.
\end{abstract}

Keywords- Wastewater plant, automatic control, water pollution, marine outfall

\section{INTRODUCTION}

Beaches and coastal waters are very sensitive areas to be polluted and problems can appear in those areas near pollution sources after a heavy rainfall or when a sewage treatment plant malfunctions. Pollution can also occur from disruption or damage of wastewater collection and treatment infrastructure due to severe natural events like hurricanes or flooding. Untreated storm water runoffs from cities and rural areas can be another significant source of beach water pollution. In some areas, boating wastes and malfunctioning septic systems can also be important local sources of beach water pollution. Combined sewer systems are designed to carry both raw sewage and storm water runoff to sewage treatment plants. New control methods are implemented in wastewater treatment plants [1][2][3], and effects of environmental factors have been also studied [4]. But even with the proposed methodologies, during heavy rainstorms these systems can become hydraulically overloaded and discharge a mixture of raw sewage and polluted runoff from streets into local waterways. The discharges pollute water around the outfalls and at downstream beaches.

Heavy rainfall can also hydraulically overload separate sanitary sewer systems which carry raw sewage to sewage treatment plants. This is especially a problem for systems with excessive infiltration of rainfall through the ground into leaky sanitary sewers and with large inflows from sources such as roof drains connected directly to sewers. When flows exceed the capacity of the system, sewers can overflow and discharge untreated sewage from manholes and bypasses at pump stations and sewage treatment plants. The discharges flow into local waterways and therefore they pollute water. People who swim in waters near storm drains can become ill. Polluted runoff and untreated sewage released into the water can expose swimmers to bacteria, viruses, and protozoans. These pathogens (diseasecausing organisms) can be present at or near the site where polluted discharges enter the water.

Catalonia is an east-northern region in Spain which is much valuated for its high quality beaches. This region receives every year 30 million tourists mainly from Europe who spend their holidays in a coastal area and most of them use to swim in the Mediterranean shores of Catalonia. Due to the high concentration of touristic resorts and a big city such as Barcelona, its coastal waters are very sensitive to pollution. Specifically, in the Mediterranean an estimated $85 \%$ of sewage flows into the sea without adequate treatment [5], creating risks of diseases such as viral hepatitis, dysentery, and poliomyelitis and typhoid, all of which are endemic in the region. In fact, it is widely accepted that the Mediterranean sea has several features, meteorological and oceanographic among others, that configure a system of complex phenomenology, such as medicanes and other unique occurrences. It is worth noting also that the Mediterranean sea's physical features, as being almost closed to other water masses, make its ecosystems vulnerable to problems associated to the lack of waters circulation and renewal, as excessive pollutant concentration, being derived from human activities or natural processes. In order to minimize the contamination of coastal waters in certain places (e.g., along beaches and in aquacultures), solutions based on the construction of submarine sewer outfalls have been proposed. But this solution, the use of submarine outfalls, constitutes at the same time a procedure for wastewater treatment, usually complementing operations on sewage treatment plants, given the appropriate weather conditions. Although these conditions are granted under normal weather conditions, and considered for placement and design of submarine outfalls, it should be noted that storms, winds and other meteorological phenomena often disrupt the treatment processes altering oceanographic conditions. 
Therefore, in some environmental limit cases, the high level of pollution in water that arrives to the beach causes diseases and damages to swimmers. Specifically, this fact occurs in the beaches of the city of Barcelona (capital of Catalonia) because of the Besòs wastewater plant. For this reason, when the emergence warning is generated, an automatic control system for regulating the water pollution (E.coli) in Besòs outfall output in an efficient and rapidly way is proposed. This automatic control system consists on a Smith Predictor (SP) scheme using a PI computed by Ziegler-Nichols method [6].

The paper is organized as follows. In section II, a description of the wastewater plant is presented. In section III, the mathematical models used in this research are presented. The control model to detect pollution in the sampled areas, that is, in the beaches in front of the outfall, is described in section IV. Based on real data, a set of results are presented during periods of beach pollution. Section $\mathrm{V}$ collects those experiments and validation with real data. Some conclusions and discussion are presented at the end of the paper.

\section{Application to Wastewater Treatment Plants}

For the proposed system, we considered a medium wastewater processing plant which treats up to $70000 \mathrm{~m}^{3}$ of water, or the

The outfall studied in this work dumps wastewater processed by Besòs sewage treatment plant. This plant is able to process up to $525,000 \mathrm{~m} 3$ of sewage water a day. Daily, in average more than $400.000 \mathrm{~m} 3$ are treated in the plant and about $80 \%$ of this sewage volume comes from population living in Barcelona Metropolitan Area. This includes about $65 \%$ of Barcelona's population, and the whole population of several cities, namely: Badalona, Mongat, Santa Coloma de Gramanet, and Sant Adrià del Besòs. The urban wastewater plant ejects treated water to the see by an outfall about $3 \mathrm{~km}$ away from the coast, as it can be seen in a rendering in Figure 1. Water received a secondary treatment (physical and biological treatment) meaning that the output water is not drinking water, still biologically polluted (bacteria, viruses...). This wastewater is dumped at $50 \mathrm{~m}$ depth in the Mediterranean Sea. The dumping area is in the diffuser section, at the end of a $2900 \mathrm{~m}$ long submarine outfall. This diffuser section has 15 dumping mouths, spaced $50 \mathrm{~m}$ between them, with four horizontal nozzles each.

The plant follows a typical scheme of well-tested procedures for wastewater treatment: upon entering, wastewater is screw-pumped to the highest peak of the plant, to be screened and removing the grit using potential energy. To improve decantation processes, wastewater receives flocculation agents in a mixing tank, prior to its dumping into primary decantation tanks. After this primary decantation has ended, the primary sludge is removed, containing up to $30 \%$ of the initial organic matter present in sewage, and wastewater is pumped to the aeration tanks, where the well-known activated sludge treatment is started. When this treatment ends, the wastewater is pumped to the submarine outfall, and the secondary sludge, containing up $60 \%$ of initial organic matter, is removed to be dehydrated and moved to Montcada sludge treatment plant.

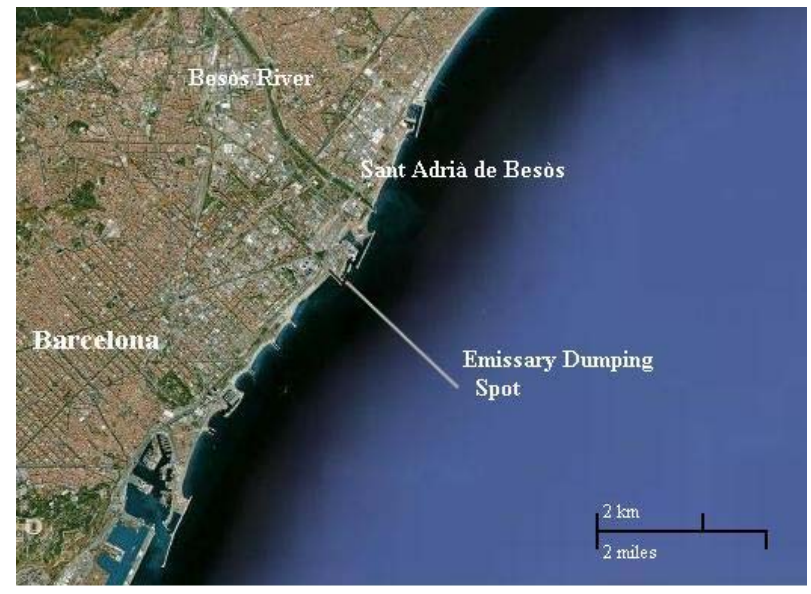

Figure 1. Location of the submarine outfall from the urban Besòs wastewater treatment plant, with its dumping zone at a distance of $3 \mathrm{~km}$ approximately from the coast in front of Barcelona city.

Thanks to the outfall, the treatment can be considered to be continued, due the effects of sea environment, concretely, diffusion and predation processes upon organic mass. Therefore, wastewater pollutant diffusion is originated in the dumping spot area, with a given initial concentration $\mathrm{C} 0$, and as the wastewater is dragged and diluted by water currents, concentration is reduced and dispersed around the area. In a general case, organic pollutant will reach coastline with very low concentrations, almost negligible. In fact, most of the days, this negligible pollution will disperse mainly towards south, in response to northern winds dominance in the area, and the circulation currents usually present in the area. But given south eastern and especially eastern winds, there exists the risk that biological pollution disperses towards the coast. This risk increases under certain meteorological conditions, as cloudy skies blocking solar radiation incidence, or cold waters inhibiting micro-biota which normally predates upon bacteriological pollutants. These particular conditions use to take place during storms with some stationary effects due to year's season.

\section{Plant CONTROL MOdel: OUtFall POLlution AND BACTERICIDAL MODEL}

The pollutant components concentration decreases along the trail formed by water currents, due transport and transformation processes which affect differently each pollutant component [7][8]. These coast pollutant concentrations can be studied through a mass conservation equation, introducing transport and transformation processes, and external gain/loss gives place to a general form mass conservation equation, or convection-diffusion-reaction equation (Eq. 1):

$\frac{\partial C}{\partial t}=-U \frac{\partial C}{\partial x}-V \frac{\partial C}{\partial y}-W \frac{\partial C}{\partial z}+\frac{\partial}{\partial x}\left[K_{x} \frac{\partial C}{\partial x}\right]+\frac{\partial}{\partial y}\left[K_{y} \frac{\partial C}{\partial y}\right]+\frac{\partial}{\partial z}\left[K_{z} \frac{\partial C}{\partial z}\right]+\lambda C+I$ (1)

where $\mathrm{C}$ is the pollutant component concentration (mass/volume); $\mathrm{U}, \mathrm{V}$, and $\mathrm{W}$ are considered water speed vector components (length/time) in $\mathrm{x}, \mathrm{y}$ and $\mathrm{z}$ axis respectively; $\mathrm{Kx}$, $\mathrm{Ky}$ and $\mathrm{Kz}$ denote turbulent diffusion coefficients (area/time) in $\mathrm{x}, \mathrm{y}$ and $\mathrm{z}$ axis respectively; and finally I refers to external 
gain/loss contribution speed (mass/volume•time). This differential equation with second order partial derivatives results in complex calculations for general case solving. Thus, several assumptions based on studied data and circumstances are taken in order to simplify this equation.

It is assumed that water currents induce a constant speed horizontal advection process, which along turbulence phenomena, yields a dilution plume. This plume grows along $x$ axis, describing depth through $z$ axis, and $y$ axis perpendicular to both. Vertical diffusion is not accounted under the assumption that the formed diffusion plume will expand through the depth, considering the sea a well-mixed mass of uniform density. All these assumptions allow to simplifying Eq. 1 into Eq.2:

$$
-U_{a} \frac{\partial C}{\partial x}+\frac{\partial}{\partial y}\left[K_{y} \frac{\partial C}{\partial y}\right]+\lambda C=0
$$

Solving this equation by the finite differences numerical method [9], being $\mathrm{Ua}$ the advective velocity and $\mathrm{C}$ the pollutant concentration at each point $(\mathrm{x}, \mathrm{y})$ of the outfall output, these values are calculated and E.coli measured in CFU/100ml.

\section{A. Modeling bactericide system}

Chlorine-based disinfectants are commonly used in wastewater treatment [10]. In order to manage coastal pollution due to the wastewater that arrives from a submarine outfall under extreme weather conditions as mentioned in the Introduction Section, authors have developed a simplified mathematical model that represents this process of disinfection. This model is of the microbial growth kind and it is represented as a generalization of the Chick's Law [11] that relates the biomass concentration at the input respect the output. This biomass is made of complex heterogeneous populations of any kind of microorganisms, interrelated among them where the species, genre and family in the system present a different population growing that depends mainly on the available food and environmental factors such as $\mathrm{pH}$, water temperature and dissolved oxygen.

The bactericidal model is formulated by means of the Conservation Mass Law and the Chick's Law that state:

$$
C_{\text {in }}(t)-C_{\text {out }}(t)=\frac{1}{k} \frac{d C_{\text {out }}(t)}{d t}
$$

From the Eq. 3, the rapidity of the variation of the biomass is proportional to the quantity of microorganisms (in our case, basically E.coli) present in a certain moment. In the literature this assumption is commonly applied to represent the microbial growing. In Eq. (3), the variables and parameters are the following: Cin is the input pollutant concentration of the wastewater, Cout is the output concentration of the wastewater, and $\mathrm{k}$ is the biomass variation parameter $\left[\mathrm{t}^{-1}\right]$ (disinfection constant) initiating at the wastewater input and the water pollution concentration at the wastewater output has been developed, and it follows the next equation:

$$
G_{b}(s)=\frac{C_{\text {out }}(s)}{C_{\text {in }}(s)}=\frac{1}{(s+k)}
$$

In the literature there are different studies about bactericidal models where the parameter $\mathrm{k}$ is estimated considering different expressions, [12][13] among the most representatives, that depend on environmental factors, such as the temperature, $\mathrm{pH}$, radiation, oxygen demand, etc. Usually, this parameter is formulated in an empirical way: $\mathrm{k}=\mathrm{kd}+\mathrm{ksI}$ where $\mathrm{kd}^{-1}\left[\mathrm{~d}^{-1}\right]$ is the background or 'dark' disinfection rate, ks $\left[\mathrm{cm}^{2} \mathrm{cal}^{-1}\right]$ is the 'light only' disinfection rate coefficient and I is the radiation [cal cm $\mathrm{cm}^{-1}$ ]. A good review of models can be found in [14].

In the cases where the variation of temperature is the most important parameter, authors use Marais formulation [12] because the temperature is the only environmental factor considered:

$$
\mathrm{kd}=2.6 \times 1.19(\mathrm{~T}-20), \mathrm{ks}=0
$$

with temperature $\mathrm{T}\left[{ }^{\circ} \mathrm{C}\right]$. In the experiments presented in this paper water temperature is considered at $21^{\circ} \mathrm{C}$ and $10^{\circ} \mathrm{C}$, in summer and winter respectively, and the disinfection constant is $\mathrm{k}=0.1289\left[\mathrm{~h}^{-1}\right]$ and $\mathrm{k}=0.019\left[\mathrm{~h}^{-1}\right]$, respectively.

In the cases where the irradiation is the most important parameter usually the Mayo, [13], formulation is used:

$$
k_{d}=0.108, k_{s}=\frac{5.74 \times 10^{-4}}{Z}
$$

where $Z[\mathrm{~cm}]$ is the sea depth. The value that authors use in these experiments for the coefficient $\mathrm{k}$ is set to 0.7687 $\left[\mathrm{h}^{-1}\right]$.

Initially, water coming from the sewage system is treated in the wastewater plant and it is thrown away to the sea by the submarine outfall. When water goes through the outfall (like a pipe in control system), a delay is introduced that can be represented as $\tau=\mathrm{L} / \mathrm{v}$, with $\mathrm{v}=\mathrm{Q} / \mathrm{A}$, where $\mathrm{L}$ is the outfall length, $\mathrm{v}$ is the water velocity, $\mathrm{Q}$ is the water flow and $\mathrm{A}$ is the outfall pipe area. In Besòs outfall, with the present geometry and conditions, the estimated delay is $\tau=0.3949 \mathrm{~h}$ (23m,41s, 64cs).

The water concentration system contains chlorine-based disinfection applied in the wastewater plant that later on is transported to the sea by the outfall. Therefore, the transfer function that relates the outfall output pollutant concentration with the input wastewater concentration is:

$$
G_{s}(s)=\frac{C_{\text {outd }}(s)}{C_{\text {in }}(s)}=\frac{1}{(s+k)} e^{-s \tau}
$$

which corresponds to a first order plus delay time (FOPDT) plant. This FOPDT transfer function in canonical form has a gain, $K=1 / k$, a time constant, $T=1 / k$ and a delay $\tau$.

\section{Automatic CONTROL System}

In order to control water pollution at the output of the outfall when there are emergency warnings, a suitable option is to dose chlorine $(\mathrm{Cl}+)$ to lower the E.Coli concentration in treated water before it goes to the sea by the outfall. This water, at the end, can reach the beaches of the city of 
Barcelona causing an unnecessary and hazardous problem to population.

The control strategy that was decided by the plant officers was carried out using a supervisor and a low level controller [15]. The supervisor is in charge of activating the control system when any warning is detected. This control system has to generate the desired reference concentration at the output of the outfall in order that the polluted water arrives to the beach without any biological danger independently of the climate conditions present in the sea in that moment. If the biological charge at the output of the outfall is too high, the sea cannot kill enough bacteria before the water reaches the coast pushed by the storm and strong associated winds. The low level controller is in charge of supplying chlorine $(\mathrm{Cl}+)$ to the concentration Cin before this water leaves the plant to the sea. The amount of chlorine to dose is controlled until the desired reference is reached. In order to guarantee the system internal stability and to compensate the system delay, an Internal Model Control (IMC) scheme is used (see Figure 2).

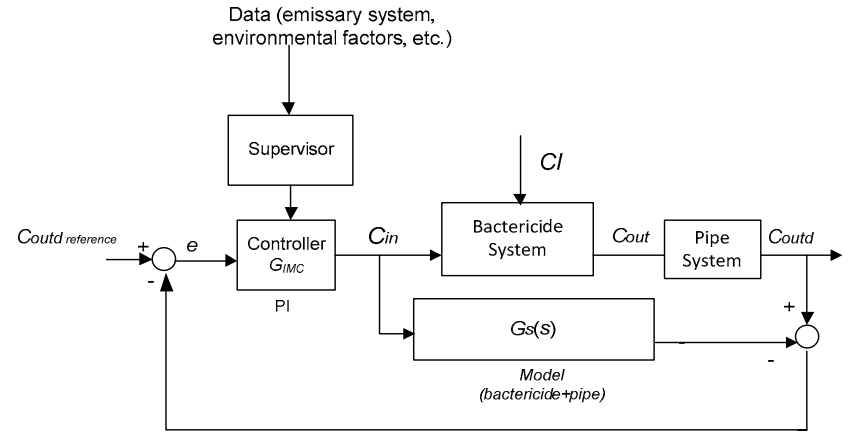

igure 2. IMC scheme of the disinfection system.

$\mathrm{F}$

When an IMC scheme is used and the system is represented by an FOPDT model, the naturally achieved controller is a simple classical PI controller. Through the IMC scheme most of the delay is compensated but, as obvious, there is a delay modelling error. In the worst case, this delay estimation error is 2.37 minutes.

It is represented by an unstructured multiplicative uncertainty [16]. Recently, a growing interest in the derivation of simple rules that offer a high level of robustness in IMC approach has appeared. In this sense, the rule SIMC is of special interest, proposed in [17] and oriented to improve the efficiency of regulation. Generally, tuning methods developed based on control techniques with internal model use pole cancellation and therefore they produce very slow responses. Taking into account this effect, in this new procedure the IMC tuning rules are modified in order to achieve swift responses in front of setpoint changes. For the PI controller tuning, a FOPDT model is used as a basis. The SIMC tuning for a PI controller (with $\mathrm{Kp}$ controller proportional constant and $\mathrm{Ti}$ controller integrator time) can be expressed as:

$$
K_{p} K=\frac{1}{2 \tau}, \quad \frac{T_{i}}{T}=\min \{1,8 \tau\}
$$

Detailed information can be found in [17].

\section{RESULTS AND DISCUSSION}

In order to test the feasibility of the automated control system using a PI controller presented in this paper, authors have prepared a set of cases that simulates real situations that happen along the year in the Mediterranean Sea. The presented control methodology is applied for these cases.

Table I and Table II show the different cases divided into 2 big sections: winter and summer cases. This division is done because there are clearly separated weather conditions in the area. The Mediterranean area, due to its location, has a mild climate without extreme conditions, but nonetheless there are some differences regarding the water temperature, wind conditions and solar radiation.

TABLE I. PARAMETERS AND OUTPUT MODEL CONCENTRATION IN WINTER

Winter cases for water temp. $=10^{\circ}$; solar altitude $=20^{\circ}$

$\mathrm{WD}=$ wind direction $($ degrees $) ; \mathrm{WV}=$ wind velocity $(\mathrm{m} / \mathrm{s}) ; \mathrm{TSS}=$
total suspended solids $\left(\mathrm{g} / \mathrm{m}^{3}\right) ; \mathrm{CC}=$ cloud coverage $($ unitary $) ;$
$\mathrm{C}=$ concentration $(\mathrm{CFU} / 100 \mathrm{ml})$

\begin{tabular}{|c|c|c|c|c|c|}
\hline Case & $W D$ & $\boldsymbol{W V}$ & $T S S$ & $C C$ & $C$ \\
\hline 1 & $45^{\circ}$ & 2 & 799 & 0.99 & 268.30 \\
\hline 2 & $45^{\circ}$ & 2 & 799 & 0.15 & 268.80 \\
\hline 3 & $45^{\circ}$ & 2 & 100 & 0.99 & 54.81 \\
\hline 4 & $45^{\circ}$ & 2 & 100 & 0.15 & 25.97 \\
\hline 5 & $45^{\circ}$ & 20 & 799 & 0.99 & 1868.90 \\
\hline 6 & $45^{\circ}$ & 20 & 799 & 0.15 & 660.00 \\
\hline 7 & $45^{\circ}$ & 20 & 100 & 0.99 & 381.70 \\
\hline 8 & $45^{\circ}$ & 20 & 100 & 0.15 & 360.00 \\
\hline 9 & $311^{\circ}$ & 2 & 799 & 0.99 & 256.80 \\
\hline 10 & $311^{\circ}$ & 2 & 799 & 0.15 & 257.00 \\
\hline 11 & $311^{\circ}$ & 2 & 100 & 0.99 & 133.75 \\
\hline 12 & $311^{\circ}$ & 2 & 100 & 0.15 & 125.36 \\
\hline 13 & $311^{\circ}$ & 20 & 799 & 0.99 & 559.70 \\
\hline 14 & $311^{\circ}$ & 20 & 799 & 0.15 & 533.70 \\
\hline 15 & $311^{\circ}$ & 20 & 100 & 0.99 & 302.90 \\
\hline 16 & $311^{\circ}$ & 20 & 100 & 0.15 & 253.70 \\
\hline
\end{tabular}

The bound values of Table III have been taken according to the Directive [18] of the European Parliament and of the Council of 15 February 2006 concerning the management of bathing water quality and repealing Directive 76/160/EEC.

The parameters that are used to select the setpoint to obtain a suitable water quality according the present European directive are the wind direction (WD, in degrees), wind velocity (WV, in $\mathrm{m} / \mathrm{s}$ ), total suspended solids (TSS, in $\mathrm{kg} / \mathrm{m}^{3}$ ), cloud coverage (CC, unity), water temperature and solar altitude (in degrees). 
For these experiments, the values that authors have chosen for each season are: 1) Winter season: water temperature $10^{\circ} \mathrm{C}$, this is an average value for the most cold months of year; the sun altitude has been taken as $20^{\circ}$ respect the horizon, a representative value for those months of the year although Barcelona is at $41^{\circ} 24^{\prime} \mathrm{N}$ latitude; 2) Summer season: water temperature $21^{\circ}$, average value for summer months, sun altitude of $45^{\circ}$, much higher than in winter time, and also very representative of Barcelona sun irradiation.

TABLE II. PARAMETERS AND OUTPUT MODEL CONCENTRATION IN SUMMER

\begin{tabular}{|c|c|c|c|c|c|}
\hline \multicolumn{6}{|c|}{$\begin{array}{l}\text { Summer cases for water temp. }=\mathbf{2 1}^{\circ} \mathrm{C} ; \text { solar incidence }=\mathbf{4 5}^{\circ} \\
\text { WD= wind direction }(\text { degrees }) ; \mathrm{WV}=\text { wind velocity }(\mathrm{m} / \mathrm{s}) ; \mathrm{TSS}= \\
\text { total suspended solids }\left(\mathrm{g} / \mathrm{m}^{3}\right) ; \mathrm{CC}=\text { cloud coverage }(\mathrm{unitary}) ; \\
\mathrm{C}=\text { concentration }(\mathrm{CFU} / 100 \mathrm{ml})\end{array}$} \\
\hline Case & $W D$ & $W V$ & TSS & $C C$ & $C$ \\
\hline 1 & $0^{\circ}$ & 2 & 799 & 0.90 & 279.10 \\
\hline 2 & $0^{\circ}$ & 2 & 799 & 0.10 & 279.08 \\
\hline 3 & $0^{\circ}$ & 2 & 100 & 0.90 & 134.40 \\
\hline 4 & $0^{\circ}$ & 2 & 100 & 0.10 & 75.68 \\
\hline 5 & $0^{\circ}$ & 20 & 799 & 0.90 & 765.30 \\
\hline 6 & $0^{\circ}$ & 20 & 799 & 0.10 & 654.06 \\
\hline 7 & $0^{\circ}$ & 20 & 100 & 0.90 & 461.92 \\
\hline 8 & $0^{\circ}$ & 20 & 100 & 0.10 & 265.60 \\
\hline 9 & $311^{\circ}$ & 2 & 799 & 0.90 & 364.40 \\
\hline 10 & $311^{\circ}$ & 2 & 799 & 0.10 & 364.80 \\
\hline 11 & $311^{\circ}$ & 2 & 100 & 0.90 & 258.97 \\
\hline 12 & $311^{\circ}$ & 2 & 100 & 0.10 & 142.47 \\
\hline 13 & $311^{\circ}$ & 20 & 799 & 0.90 & 725.77 \\
\hline 14 & $311^{\circ}$ & 20 & 799 & 0.10 & 625.78 \\
\hline 15 & $311^{\circ}$ & 20 & 100 & 0.90 & 397.10 \\
\hline 16 & $311^{\circ}$ & 20 & 100 & 0.10 & 247.80 \\
\hline
\end{tabular}

TABLE III. LIMIT VALUES FOR WATER QUALITY

\begin{tabular}{|c|c|c|c|c|}
\hline \multicolumn{4}{|c|}{ Coastal waters and transitional waters quality limits } \\
\hline \multirow{2}{*}{ Parameter } & \multicolumn{3}{|c|}{ Quality (CFU/100ml) } & $\begin{array}{c}\text { Reference } \\
\text { methods of } \\
\text { analysis }\end{array}$ \\
\cline { 2 - 5 } & Excellent & Good & Sufficient & $\begin{array}{c}\text { ISO 9308-3 } \\
\text { or } \\
\text { ISO 9308-1 }\end{array}$ \\
\hline $\begin{array}{c}\text { Escherichia } \\
\text { coli }\end{array}$ & 250 & 500 & 500 & \\
\hline
\end{tabular}

For the remainder parameters values, the following values have been taken, as representative values. Authors chose two values for most of them, quite different one from the other, to see the model behaviour in front those combination of values.
Each combination has a real meaning and it appears during the year.

Winter season values:

- Wind direction: $45^{\circ}$ and $311^{\circ}$,

- Wind velocity: 2 and $20 \mathrm{~m} / \mathrm{s}$,

- Total suspended solids: 799 and $100 \mathrm{~g} / \mathrm{m}^{3}$, this parameter is considered as a water quality measurement,

- Cloud coverage: 0.99 and 0.15 respect 1 . This fraction corresponds to the amount of clouds in sky, a value of 1 corresponds to complete coverage of the sky, and a value of 0 means no clouds at all in the sky.

Summer season values:

- Wind direction: $0^{\circ}$ and $311^{\circ}$,

- Wind velocity: 2 and $20 \mathrm{~m} / \mathrm{s}$,

- Total suspended solids: 799 and $100 \mathrm{~kg} / \mathrm{m}^{3}$, this parameter is considered as a water quality measurement,

- Cloud coverage: 0.90 and 0.1 respect 1 , more realistic values for this season.

The wind direction is restricted to those orientations that really can carry bacteriological material to the beach, because the outfall is located to the east of the shore, and only a range of directions are of interest to study the pollution at the beach; those values range from $280^{\circ}$ to $60^{\circ}$. Moreover, the Catalan coast is slightly oriented from NNE to SSW, having its normal at $311^{\circ}$ in the area of study.

The choice of wind velocity is based on realistic values, ranging from a gentle breeze $(2 \mathrm{~m} / \mathrm{s})$ during most of the time in this area to storms $(20 \mathrm{~m} / \mathrm{s})$ that appear at the end of summer (2nd-3rd week of September mainly) and in winter. Those winds can happen with rain (a high cloud coverage ratio) or in sunny days (low cloud coverage ratio). The value for suspended solids also appear from the experience in the Mediterranean shores, happening episodes of high pollution some days of the year or low pollution other periods. Authors consider that the values chosen to the experiments cover a wide range of combination that as a matter of fact cover most of the time of winter and summer periods.

The behaviour of the model using the parameters representing the winter season can be seen in Table I. The output of the model, expressed as the microbial contamination by bacteria, which is expressed in Colony Forming Units (CFU), a measure of the bacterial population, can be seen in column with " $C$ ", concentration. As a reference of this output, in Table III the limits set by the European Community for the quality of coastal waters can be appreciated. All those concentration values below $500 \mathrm{CFU} / 100 \mathrm{ml}$ represent accepted concentrations to consider the beaches as allowed bathing areas, whereas those values above this limit represent coastal pollution and therefore the bath ban in beaches. In some cases, the limit of $500 \mathrm{CFU} / 100 \mathrm{ml}$ is reached, and thus the beach should be closed for bathing activities. Fortunately, this limit is achieved only in very special conditions and it happens in average 2-3 times a year. During the winter season, 
it is not very significant the coastal pollution because the null activity in the beaches but nevertheless, it is reached in cases $5,6,13$ and 14. In those cases, the wind velocity was high $(20 \mathrm{~m} / \mathrm{s})$ as well as the suspended solids $\left(799 \mathrm{~g} / \mathrm{m}^{3}\right)$ and it does not depend on the cloud coverage, the wind is so high that the sun cannot kill enough bacteria during their travel to the beach. For the rest of cases, the output concentration of the model is always below the allowed limit.
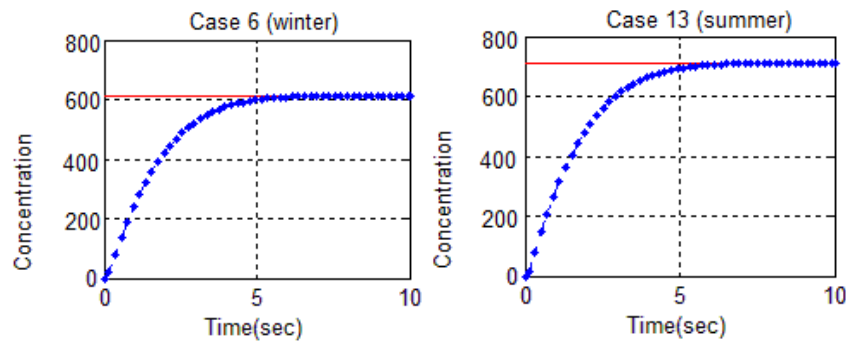

Figure 3. Control results in case 6 (winter) and case 13 (summer).

The concentration is expressed in CFU/100ml, reaching values above the recommended ones for bathing.

During the summertime, the output concentration values are higher than in winter because the water temperature and the irradiation in summer permit that bacteria can develop more rapidly. However, the pollution episodes are still rare and only in cases 5, 6, 13 and 14 the output values are above the pollution limits. In summertime, the values are in general in the range of good-sufficient quality due to the mentioned reasons. Those values have been compared with the historic values registered in the monitoring stations and there is a high coincidence with the episodes forecasted with the proposed model. Once the meteorological parameters are known, it is possible to select the setpoint to achieve a suitable water quality in the coast when there is any warning of pollution in the beach; in that moment the automatic control is activated to avoid that polluted water arrives to the coast.

Next, the control results of the cases 6 and 13 for winter and summer, respectively, can be seen in Figure 3. The plant (wastewater and outfall) pollutant concentration has a different behaviour in cases 6 (winter) and case 13 (summer), but in both cases the biological charge that arrives to the coast is above the allowed values in the European Directive for safe bathing. The automation of the disinfection system by the control scheme that cancels the delay and supplies the needed chlorine amount takes in average 5 minutes in both cases, when in regular circumstances, after a manual process, could take 2-3 hours to act and regulate the pollution in the water.

\section{CONCLUSIONS}

A novel automatic control system has been presented in order to cancel the water pollution in the coast. Under certain weather conditions, the biologically polluted water that the outfall of the Besòs wastewater plant throws to the sea arrives with bacteria levels higher than the recommended ones by a European Directive of safe bathing. In those cases, the beaches have to close the access to the population until the hazard disappears. With the new control system that authors present in this research, when those weather conditions are present, the wastewater is chlorinated in the plant before been thrown to the sea with a potential danger to pollute the coast. The automatic system is based in a Smith Predictor that cancels the delays in the outfall and sea water transport, reducing drastically the time to act before any emergence warning is generated.

\section{REFERENCES}

[1] Samsudin, S.I., Rahmat, M.F. and Norhaliza Abdul Wahab "Nonlinear PI Control with Adaptive Interaction Algorithm for Multivariable Wastewater Treatment Process", Mathematical Problems in Engineering, Volume 2014 (2014), Article ID 475053, 13 pages, http://dx.doi.org/10.1155/2014/475053.

[2] Yong Zhang, Tingsheng Zhao, Aijiao Zhou, Zhengzhu Zhang, and Wen Liu, "Scenario Based Municipal Wastewater Estimation: Development and Application of a Dynamic Simulation Model", Modelling and Simulation in Engineering, Volume 2016 (2016), Article ID 1746310, 13 pages, http://dx.doi.org/10.1155/2016/1746310

[3] Meneses, M., Concepción, H. and Vilanova, R., "Joint Environmental and Economical Analysis of Wastewater Treatment Plants Control Strategies: A Benchmark Scenario Analysis", Sustainability 2016, 8(4), 360; doi:10.3390/su8040360.

[4] Liu, L., Hall, G. and Champagne, P., "Effects of Environmental Factors on the Disinfection Performance of a Wastewater Stabilization Pond Operated in a Temperate Climate", Water 2016, 8(1), 5; doi:10.3390/w8010005.

[5] Kellis, M., Kalavrouziotis, I.K., Gikas, P., "Review of Wasterwater Reuse in the Mediterranean Countries, focusing on Regulations and Policies for Municipal and Industrial Applications", Global NEST Journal, Vol 15, No 3, pp 333-350, 2013.

[6] Gámiz, J., and Gámiz, J., "PID parameters tuning in control loops for industrial processes", Revista Técnica Industrial, vol. 290, pp. 46-50, December, 2010, (in Spanish), http://www.tecnicaindustrial.es/TIAdmin/Numeros/75/386/a386.pdf, last accesed February 2017.

[7] Abril, J.M. and Abdel-Aal M. M., "A modelling study on hydrodynamics and pollutant dispersion in the Suez Canal", Ecological Modelling, vol.128(1), pp.1-17, April 2000.

[8] Carreras P.E. and Menéndez, A. N., "Mathematical simulation of pollutant dispersion”, Ecological Modelling, vol. 52, pp. 29-40, 1990.

[9] Randall LeVeque, Finite Difference Methods for Ordinary and Partial Differential Equations: Steady-State and Time-Dependent Problems (Classics in Applied Mathematic), Siam Ed., 2010.

[10] Gamiz, J.; Bolea, Y.; Grau, A.; Gamiz, J.; Luque, F.; Vargas, J.M., "Automation of chlorination process for drinking water treatment plant: Control strategies", 10th IEEE International Conference on Industrial Informatics, INDIN, pp. 337-341, 2012.

[11] Chick, H., "An investigation of the Laws of Desinfection", The Journal of Hygiene, vol. 8(1), pp.92-158, 1908.

[12] Marais, G.R., "Faecal bacteria kinetics in stabilization ponds", J. Env. Engrg Div., Am. Soc. Civ. Engrs, 100 (1), pp. 139-199, 1974.

[13] Mayo, A.W., "Effect of pond depth on bacterial mortality rate", J. Envir. Engrg. ASCE, 155 (5), pp. 964-997, 1989.

[14] Liu, S., Fecal Coliform Decay and Regrowth Kinetics in an Anearobic Dairy Wastewater Environment, MsC. Thesis, Louisiana State University, May 2002.

[15] Leva, A. and Colombo, A.M, "On the IMC-based synthesis of the feedback block of ISA PID regulators", Transactions of the Institute of Measurement and Control 26(5), pp.417-440, 2004.

[16] Sanchez Peña, R.S. and Sznaizer, M., Robust Systems Theory and Application, John Wiley \& Sons, New York, 1998.

[17] Skogestad, S., "Simple analytic rules for model reduction and PID controller tuning", Journal of Process Control 13, pp.291-309, 2003.

[18] Directive 2006/7/EC, Official Journal L 064, 04/03/2006, pp. 37-51. 2006. 